\title{
Rurban Areas as Reflected in Lithuanian Territorial Planning Documents
}

\author{
Indrè Gražulevičiūtè-Vileniškè, Erika Zaleskienè, Kaunas University of Technology
}

\begin{abstract}
The research focus is the territorial planning documents of different level valid in the territory of Lithuania, and the phenomenon of rural-urban interface reflected in them. The methods applied include the desktop study aimed at determining the presence of rural-urban influence, the character of rurban landscapes, their potential, current state of their management and development possibilities as reflected in the existing planning documents. The conclusions demonstrated not only the presence and the fragmented character of rurban areas in Lithuania, but also their potential as representative and widely accessible accumulation of cultural heritage and exceptional landscape feature of the country.
\end{abstract}

Keywords - Landscape, landscape management, Lithuania, planning document, rurban areas, rural-urban interface, territorial planning.

\section{INTRODUCTION}

The interest in rural-urban interface areas, here referred to as rurban areas is on the rise both in the world and in Lithuania [1], [2], [3]. They are being more and more considered not just as rural or natural areas invaded by urbanization, but as a particular type of landscape with its own features, problems and possibilities. The field of territorial planning with its multiple interconnected levels and types of planning documents is a way to develop territories and landscapes, including the rurban ones, in a more sustainable way. The analysis of the existing territorial planning documents of particular country or region was performed on the following issues:

- development possibilities or rurban areas;

- $\quad$ presence of rural-urban influence in the country or region;

- the character of rurban landscape (including natural conditions, functions, structure, development problems and identity);

- the potential of rurban areas;

- the state of management of rurban areas as reflected in the territorial planning documents.

The aim of the research was to analyze the selected valid Lithuanian territorial planning documents at national, municipality, and local levels and to identify the development peculiarities and possibilities of rural-urban interface areas according to the above listed issues in Lithuanian context.

The research was done through the desktop study of literature, of the contents of documents regulating territorial planning in the Republic of Lithuania, and the contents of the selected Lithuanian territorial planning documents (Table I). While analyzing the planning documents of the district municipality and lower levels we concentrated on three major cities with their zones of influence - the capital city Vilnius, the second largest city sit- uated in the central part of the country - Kaunas, and the port city Klaipeda. The three cities can be characterized by active rural-urban interaction processes as well as by the diverse and distinctive features of the surrounding landscape. The research is limited to the territory of the country, where the above-mentioned documents are valid and do not address the supranational levels.

\section{Results And Discussion}

\section{A. Development Possibilities}

Lithuanian territorial planning system is concisely introduced by E. Ramanauskas and L. Dringelis [3]. The Law on Territorial Planning of the Republic of Lithuania identifies the territorial planning as the process directed towards sustainable development of country's territory and distinguishes complex (general/master and detailed plans) and special territorial planning documents. Complex territorial planning theoretically aims at determining the trends of spatial development, the priorities of preservation and the use of the territories under consideration. Special territorial planning documents are aimed at determining the means of use, management, and preservation of the areas intended for specific purpose according to the level of territorial planning. The Law distinguishes three levels of territorial planning - national (territory of the country or its parts), municipal and local (territories of urban settlements and their parts, etc.) [4]. The emphasis on the complexity of the approach and the planning of the spatial structure of the territories embodied in the Law and the array of possible types of planning documents such as general plans of the territory of the country and its parts, general plans of municipalities or their parts, detailed plans, various special plans - land management documents, special plans of protected areas, plans concerning the protection of immovable cultural heritage, plans for the development of engineering infrastructure, etc. theoretically allow the sustainable development of rurban areas by means of territorial planning.

\section{B. Influence}

The zones of direct influence of the largest Lithuanian cities can be characterized by higher density of inhabitants, relatively larger built-up areas, higher real estate prices than in other areas, and more favourable conditions for the land use conversions as demonstrated in the case of the capital city Vilnius [5]. The concept of the influence of urban settlement on the surrounding areas can be further expanded and subdivided into visual, aesthetic, social, economic, as well as the influence on the image of 

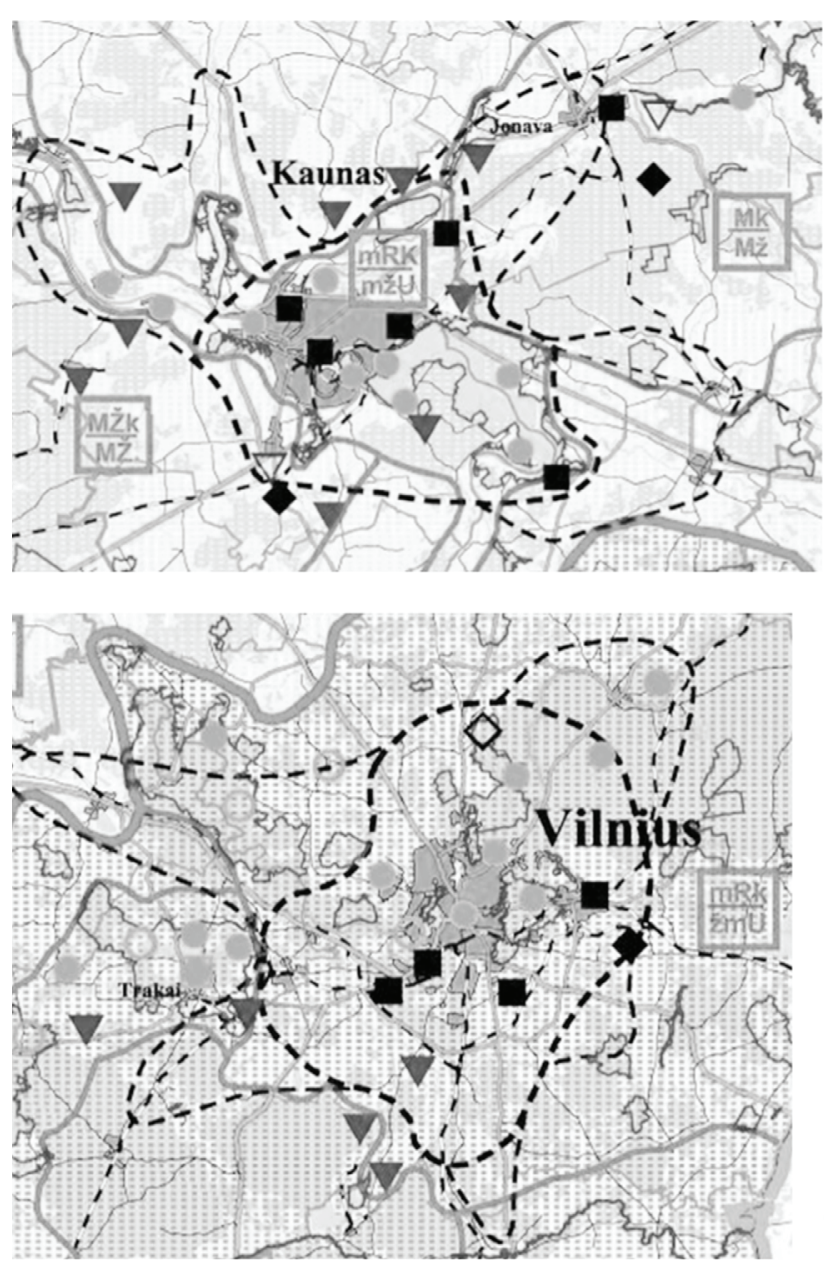

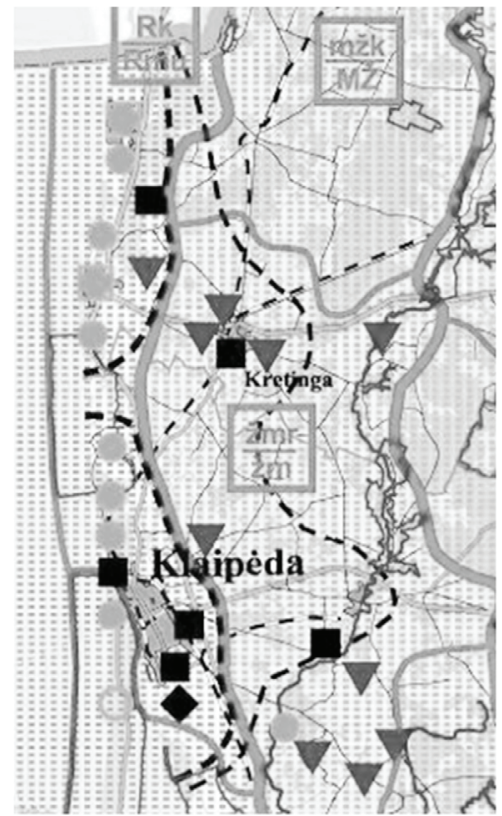

Functional priorities of the territories:

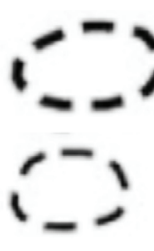

Present interests of agglomeration development

Perspective interests of agglomeration development
Areas of functional priorities

Indices of multifunctional

\section{Rmžv zoning}

\begin{tabular}{l}
\hline - Priority interests \\
\hline - Background use
\end{tabular}

$\check{Z}$ - Intensive agriculture

$\check{Z}$ - Protective agriculture

M - Intensive forestry

m - Protective forestry

$\mathrm{R}$ - Intensive recreation

$r$ - Extensive recreation

$\mathrm{V}$ - Marine fishing

V - Fishing in inland waters

L - Marine shipping

U - Agglomeration urbanization

U - Dispersed urbanization

K - Institutionally organized conversion

k - Conversion determined by law

Fig. 1. The presence of rural-urban interface in territorial planning documents of national level: the fragment of the main drawing of the Master Plan of the Territory of the Republic of Lithuania showing the zones of influence of Vilnius, Kaunas and Klaipeda [6].

the territory etc.; the comparably large urban centre defines the image of substantially large surrounding territory. For example, a county - the territorial unit in Lithuania - usually takes the name of its major city, where the influence on the territory's image and the economy can be mostly felt; district municipality surrounding the territory of the municipality of the city also has the city's name and the influence of the city on the image and the economy, the population and the landscape can be identified. P. Aleknavicius and J. Valciukiene had identified the radius of $25 \mathrm{~km}$ of influence of Vilnius city on the surrounding territory [5]. Our analysis demonstrated that the appreciable influence of the city approximately coincides with the territory of the district municipality and major attention should be paid to the territories of the elderships bordering with the territory of the municipality of the central city.

Two major territorial planning documents of national scale reflecting the influence of urban areas on countryside can be distinguished - the General Plan of the Territory of the Republic of
Lithuania and the National Landscape Management Plan of the Republic of Lithuania. For example, the main drawing of the General Plan of the Territory of the Republic of Lithuania shows the zones of the present and perspective agglomeration interests surrounding Lithuanian cities (Fig. 1) [6]. In the National Landscape Management Plan the general landscape character is marked with different colours and reflects the existence of mixed or transitory character areas surrounding the cities under analysis [7].

The municipality level planning documents reflect the rural-urban influence as well. For example, the drawings in the General Plan of Kaunas District Municipality, Special Landscape Plan of Vilnius District Municipality demonstrate the continuity of densely built-up structures outside the official boundaries of city municipalities [7], [8]. The territorial extent of the planning documents of municipality level reflects the presence of rural-urban interface as well. For example, Vilnius district municipality has a separate planning document (general plan) for its more intensely urbanized part called "the U zone" according to its configuration 

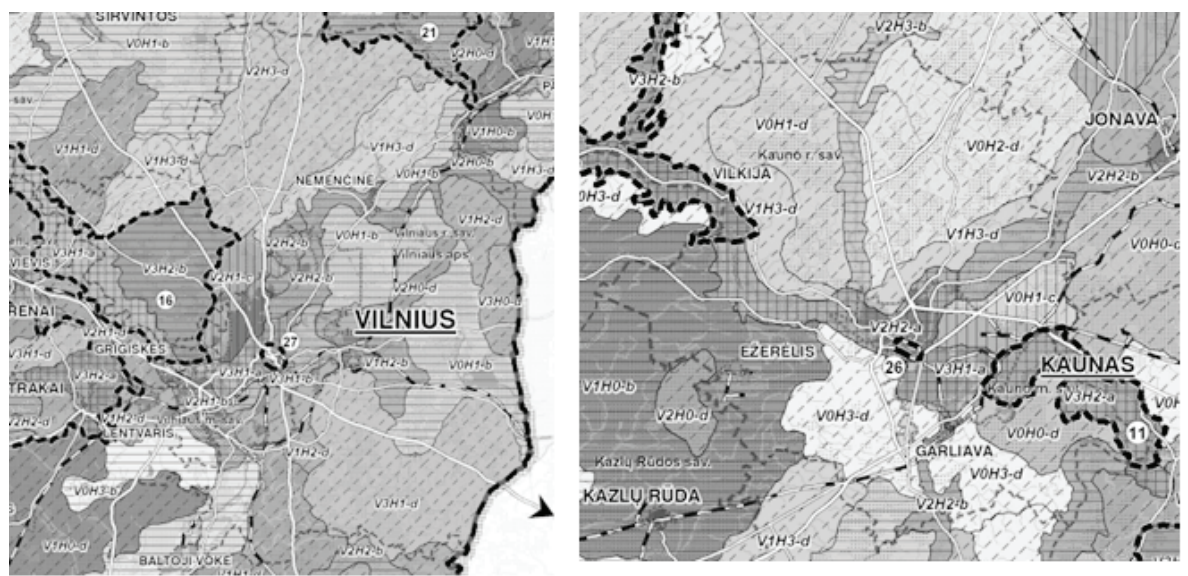

Fundamental types of visual structure

Landscape of open and semiopen spaces of very expressive and medium vertical division

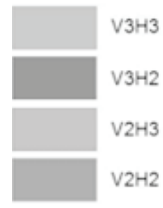

HO-landscape of closed spaces ... H3 - landscape of open spaces VO-non-expressive vertical division ... V 3 - very expressive vertical division
Landscape of spaces of various transparency of weak vertical division

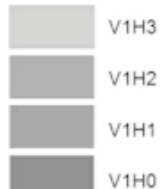

12
Landscape of closed and semi-closed spaces of very expressive and medium vertical division

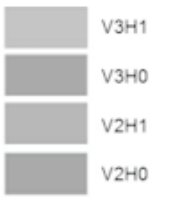

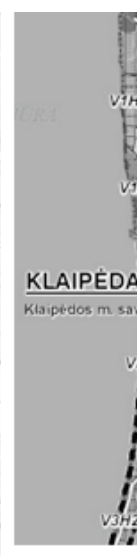
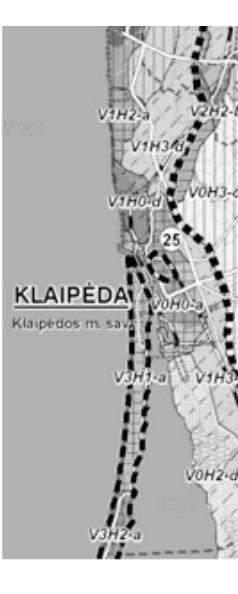

\section{Visual predominance in} landscape

Landscape of spaces of
various transparency of
non-expressive vertical
division

Fig. 2. The fragments of the $3^{\text {rd }}$ drawing of the National Landscape Management Plan of the Republic of Lithuania showing the expressive picturesque landscapes extending in the zones of influence of the large Lithuanian cities [7].

encompassing the territories of seven more intensely urbanized elderships (circa 10000 ha), which border with the territory of the municipality of Vilnius city [9].

Most of the local level planning documents, such as detailed plans for the territories and lots at the urban fringe or in the zone of urban influence, are the reflection and tools of urbanization of the countryside as one of the main purposes of these plans is the land use change from agricultural to residential [10], [11], [12].

\section{Landscape Character. Natural Conditions}

The natural conditions in territories where rural-urban interface occurs are the important feature of their character and identity. The analysis of the National Landscape Management Plan demonstrates that the diverse, expressive, picturesque landscapes extend in the zones of influence of the large Lithuanian cities. Fig. 2, 3 shows the peculiarities of visual expression of the country's landscape by distinguishing the fundamental types of visual structure of landscape, determined by the combination of the degree of expression of horizontal and vertical division of landscape, the type of their visual predominance and some ar- eas and places of highly recommended conservation due to their visual and aesthetic potential. It can be seen in Fig. 2, that the territories surrounding Vilnius, Kaunas and Klaipeda (extending in the district municipalities of these cities) encompass the areas of strongly protected aesthetic potential determined by this document, as well as a part of the recommended seashore zone of visual protection extends in the territory of Klaipeda district municipality. The mosaic of landscapes of different degrees of vertical division and of openness of spaces including the landscapes of strongly expressed vertical division and with the visual predominance in landscape of expressed complex horizontal and vertical, expressed horizontal, and expressed vertical landmarks is characteristic for the zones of influence of Vilnius and Kaunas. The zone of influence of Klaipeda city is characteristic for its seashore landscape with the mosaic of horizontal, vertical, and complex landmarks [7]. The heritage and cultural landscape aspects are discussed in the next section regarding the potential of rurban areas. The diverse landscape character, the mosaic of green, open, and built up areas, is visible in the municipality level planning documents as well. 

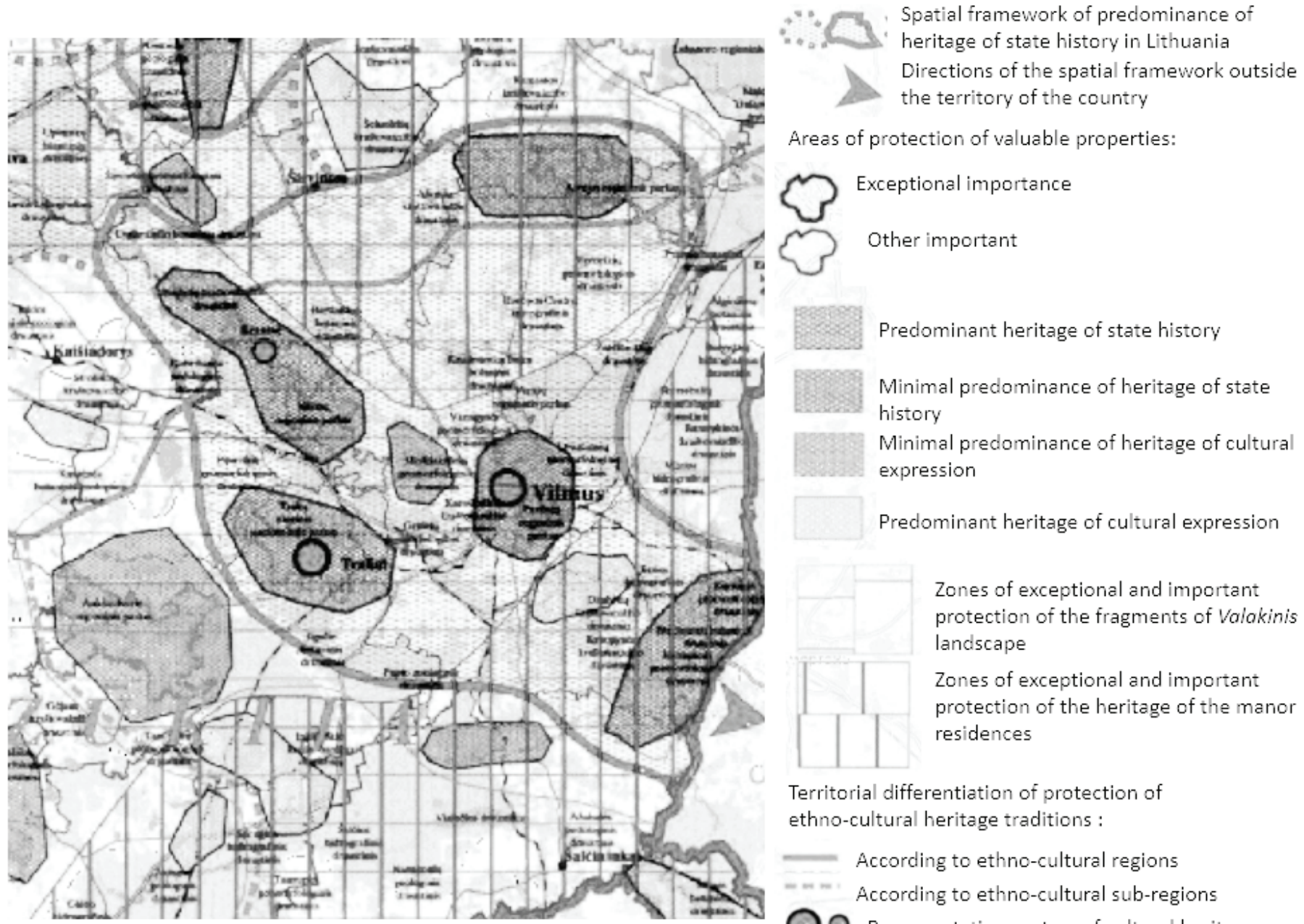

Areas of protection of valuable properties:

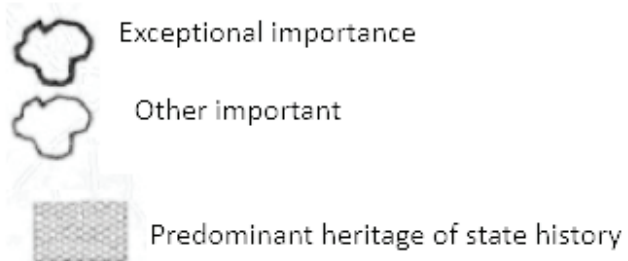
Minimal predominance of heritage of state history
Minimal predominance of heritage of cultural expression

Predominant heritage of cultural expression

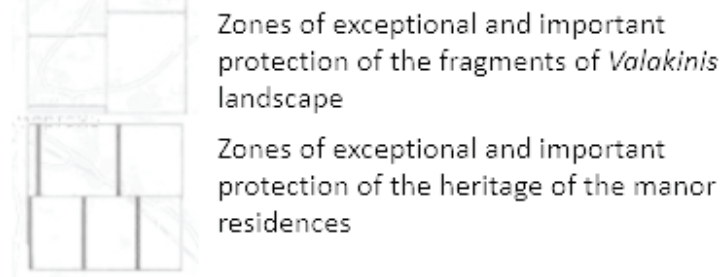

Territorial differentiation of protection of ethno-cultural heritage traditions :

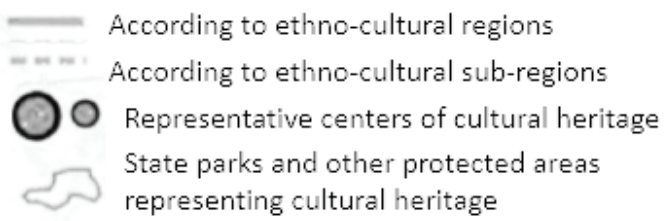

Fig. 3. The fragment of the drawing showing the cultural heritage territories of the General Plan of the Territory of the Republic of Lithuania in Vilnius and its surroundings [6].

\section{Functions}

The main drawing of the General Plan of the Territory of the Republic of Lithuania shows the indices of multifunctional zoning indicating that forestry and agriculture, the traditional land use in the countryside, are very important in rurban zones along with urban driven interests of recreation, urbanization and conversion of territories [6]. Other planning documents, using different classifications, show the presence of functionally transitory zones. For example, the National Landscape Management Plan shows the zones of interaction of urban and natural or rural environment as the rigid junction of urbanized and agrarian or natural landscapes or as transitory zones of the agrarian urbanized, the agrarian slightly urbanized, etc. landscapes. More intense fragmentation of functional zones is also visible in the zones of influence of large cities [7]. According to the Special Landscape Management Plan of Klaipeda District Municipality, in the territory of this municipality the cultured landscape consists of agrarian forested (28.48 percent), agrarian (26.78 percent), agrarian slightly urbanized (19.29 percent) and agrarian urbanized (17.97 percent) types of landscape [14]. The detailed plans of rurban zones also reflect the functional character - residential function, mainly suburban individual housing, of these areas [11], [12], [13].

\section{E. Structure}

The layout and the spatial structure of rurban areas can be easily analysed using the drawings of general and special plans of district municipalities. The drawing from the General Plan of Kaunas District Municipality showing the land use demonstrates the continuity of intensive urbanization outside and alongside the official boundaries of the city municipality, the fragmentation of landscape structure in the zone of influence of the city and the transition from urban to rural [9]. The character of peripheral 
territories of the city territory is also important from this point of view. For example, the drawing showing the planning outcomes of the Master Plan of Kaunas reflects the character of the city's fringe areas - the residential areas of the built-up structure of low intensity; although the document indicates that these territories should be provided with necessary social, commercial infrastructure, services, etc. [15], the commonly known fact is that there is scarce infrastructure in low density urban periphery and in further extending rurban areas. According to the analyses of $\mathrm{R}$. Gaudesius [16], the detailed plans of rurban zones also reflect the structure (low density point-like or patch like) of rurban areas.

\section{F. Problems and Identity}

The problems related with rurban areas are reflected both in the drawings and the explanatory material of the planning documents. The drawings and the explanatory text of the concept stage of the Special Landscape Management Plan of Klaipeda District Municipality demonstrate and describe the so-called problem areas in the municipality's territory. The majority of the identified problems is linked with the pressure for the development and increased anthropogenic activities related with the vicinity of active urban centre. The document distinguishes the types of areas which have the following characteristics: 1) conflicts of intensive recreation, urban expansion, bio-production and interest in conservation; 2) deforestation, erosion, intensive bio-production, and urbanization; 3 ) conflicts of nature and cultural heritage preservation and difficulties of implementing the regulations of protected areas; 4) unorganized and intensive urban expansion resulting in chaotic urbanization and the emergence of the suburban architecture diminishing the aesthetic value of landscape; 5) conflicts between the intensive use of mineral deposits and other uses, such as environmental preservation and recreation. However, the authors of the document mention not only the pressure for development and problems of coordination of the regulations of different planning documents characteristic to rurban zones, but also the processes related with the abandonment of land, cultural heritage objects, agricultural buildings, and re-naturalization of territories [14]. The above reviewed problems of Klaipeda district can be seen in the zones of influence of other large Lithuanian cities as well and are visible in the drawings of General plans of Vilnius and Kaunas district municipalities, Special Landscape Plan of Vilnius district municipality, etc. and can be partially deduced from the planning documents of national level.

\section{G. Potential}

The zones of influence of large Lithuanian cities can be seen as the accumulation and representation of the country's heritage and landscape (Fig. 3). Natural conditions that determine the exceptional character of rurban areas under analysis were introduced in the Sub-section Problems and identity. These expressive landscapes with water bodies are characteristic for the concentration of cultural heritage of different types. Let us take, for example, the territorial planning documents of national level. The drawing showing cultural heritage territories of the General
Plan of the Territory of the Republic of Lithuania (Fig. 3) demonstrates that the capital city Vilnius as well as Kaunas and Klaipeda are important parts of spatial framework, where the heritage representing the Lithuanian state is predominant. The zones of influence of Vilnius, Kaunas, and Klaipeda encompass valuable accumulation of areas of heritage representing the legacy of the state and of cultural expression, centres important from the cultural heritage point of view; the zones of influence of Kaunas and Vilnius encompass the protected areas as well. The important relicts of Valakinis historic rural landscape type and the landscape characteristic for its manor residencies extend in the zone of influence of Vilnius and it is mainly the important relicts of Valakinis historic rural landscape type that extend in the zone of influence of Kaunas [6]. The National Landscape Management Plan shows that the zones of influence of the three cities under analysis overlap with the zones of accumulation of the areas of heritage of national significance. The areas of heritage significant to the state history, the areas of archaeological architectural ethno-cultural and urban heritage, etc. overlap in the zones of influence of Vilnius, Kaunas, and Klaipeda [7].

Rich cultural landscape in the zones of influence of the largest Lithuanian cities requires not only the awareness of urban pressure and preservation, but also has a potential for representation, revival and the sustainable use of country's heritage as well as the development of tourism and cultural routes due to good accessibility from the central cities and the developed communications linking Vilnius, Kaunas, and Klaipeda.

As it was mentioned above, the central city influences the image of the substantially large surrounding territory, for example, a county. However, it is necessary to note that rurban areas, especially the ones extending at the fringe of the city and having characteristic natural and rural heritage features, can influence the image of the central city as well. The analyzed planning documents demonstrate the untapped potential of urban fringe in the development of the image of the city; for example, the solutions of the Master Plan of Kaunas demonstrate that the built heritage and the objects and areas determining the identity of the city identified by the planners are mainly concentrated in the city's central part [15]; meanwhile the features characteristic to rurban environment (including the cultural heritage of the rural origin) are not identified as shaping the city's identity. The heritage and landscape values identified above and the new interventions that occur due to urban pressure and territorial expansion of urbanized areas create peculiar landscape aesthetics or visual quality at urban fringe, which must be regulated and enhanced as a constituent of the image of urban area.

\section{H. Management}

Theoretically the territorial planning documents of all levels can serve as an effective tool for the development and management of rurban areas. The analysis of the existing planning documents has revealed some attempts directed towards this goal. For example, the national level planning document General Plan of the Territory of the Republic of Lithuania shows the functional priorities, spatial development concept, and urban framework of 

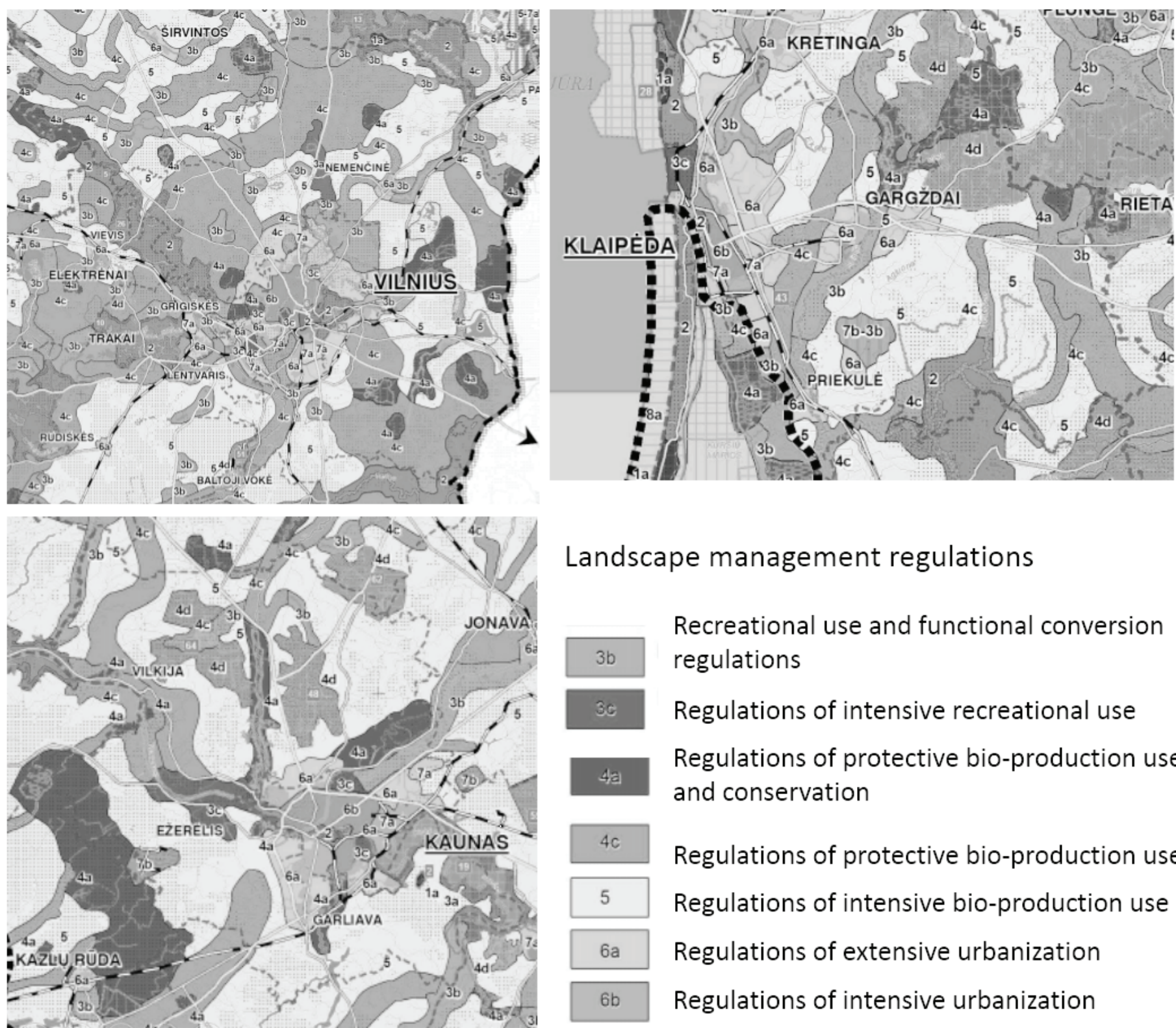

Landscape management regulations

3b
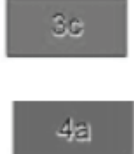

$4 \mathrm{c}$

5

$6 a$

$6 b$

\section{Recreational use and functional conversion regulations}

Regulations of intensive recreational use

Regulations of protective bio-production use and conservation

\section{Regulations of protective bio-production use}

Regulations of intensive bio-production use

Regulations of extensive urbanization

Regulations of intensive urbanization

Fig. 4. The fragments of the $2^{\text {nd }}$ drawing of the National Landscape Management Plan of the Republic of Lithuania showing the landscape management regulations in the zones of influence of Vilnius, Kaunas, and Klaipeda [7].

the territory of the country thus identifying the zones of future development and the influence of agglomeration of urban centres (Fig. 1) [6]. Drawing 2 in Fig. 4 of the National Landscape Management Plan demonstrates the distribution of the landscape management regulation strategies and trends in the cities of Vilnius, Kaunas, Klaipeda and their surrounding district municipalities. The regulations of extensive urbanization are mainly identified for the territories at the fringe of the cities under this analysis. These regulations of extensive urbanization are vaguely defined in the explanatory text of the document, thus it is difficult to envision the character and the features of landscape, that should be developed in rurban areas [7]. District municipality level planning documents - general and special landscape plans, can be analyzed from this point of view as well. The Special Landscape Plan of Vilnius District Municipality in its concept drawing envisions the diverse mix of valuable cultural and natural features and territories in the zone of influence of Vilnius. Closer look at the development solutions reveals extensive urbanization patterns with the majority of urban expansion concentrated alongside the transport routes and some dispersion of urbanization into the countryside mainly based on the expansion of the existing settlements [8]. The General Plan of Kaunas District Municipality envisions a more concentrated pattern of rurban development with the priority areas for residential development mainly bordering with the limit of the territory of the city. Meanwhile the priority territories for industry, logistics, and commerce are concentrat- 
TABLE I

Summary of the Analyzed Lithuanian Territorial Planning Documents [6]-[15] (Authors of the Article)

\begin{tabular}{|c|c|c|}
\hline $\begin{array}{l}\text { Level according to the } \\
\text { Law on Territorial } \\
\text { Planning }\end{array}$ & $\begin{array}{l}\text { Types of documents / analyzed } \\
\text { documents }\end{array}$ & Aspects related to rurban areas \\
\hline \multirow[t]{4}{*}{ National level } & \multirow[t]{4}{*}{$\begin{array}{l}\text { General Plan of the Territory of } \\
\text { the Republic of Lithuania } \\
\text { National Landscape Management } \\
\text { Plan of the Republic of Lithuania }\end{array}$} & $\begin{array}{l}\text { Rural-urban influence } \\
\text { - } \quad \text { zones of present and perspective agglomeration interests } \\
\text { existence of mixed character or transitory landscape areas in the zones of influence of } \\
\text { cities }\end{array}$ \\
\hline & & $\begin{array}{l}\text { Rurban landscape characteristics } \\
\text { - } \quad \text { presence of diverse, expressive, picturesque landscape in rurban zones } \\
\text { - } \quad \text { indices of multifunctional zoning } \\
\text { - } \quad \text { presence of functionally transitory zones in rurban areas }\end{array}$ \\
\hline & & $\begin{array}{l}\text { Potential of rurban areas } \\
\text { - } \quad \text { expressive landscape with water bodies characteristic for concentration of cultural } \\
\text { heritage of different types } \\
\text { Vilnius, Kaunas and Klaipeda as important parts of the spatial framework, where heritage } \\
\text { representing the Lithuanian state is predominant } \\
\text { developed communication linking Vilnius, Kaunas, and Klaipeda }\end{array}$ \\
\hline & & $\begin{array}{l}\text { Management of rurban areas } \\
\text { - } \quad \text { functional priorities, spatial development concept, and urban framework of the territory of } \\
\text { the country } \\
\text { - } \quad \text { zones of future development and the agglomeration influence of urban centres } \\
\text { - distribution of landscape management regulation strategies and trends } \\
\text { regulations of extensive urbanization }\end{array}$ \\
\hline \multirow[t]{4}{*}{ Municipality level } & \multirow{4}{*}{$\begin{array}{l}\text { General Plan of Kaunas } \\
\text { General Plan of Kaunas District } \\
\text { Municipality } \\
\text { Special Landscape Plan of } \\
\text { Vilnius District Municipality } \\
\text { Special Landscape Management } \\
\text { Plan of Klaipeda District } \\
\text { Municipality (concept stage) }\end{array}$} & $\begin{array}{l}\text { Rural-urban influence } \\
\text { - } \quad \text { continuity of the densely built-up structures outside the official boundary of the city } \\
\text { municipalities }\end{array}$ \\
\hline & & $\begin{array}{l}\text { Rurban landscape characteristics } \\
\text { - } \quad \text { diverse landscape character, mosaic of green, open, and built up areas in rurban zones } \\
\text { - } \quad \text { intense fragmentation of functional zones in rurban areas } \\
\text { - } \quad \text { fragmentation of landscape structure } \\
\text { - } \quad \text { residential areas of built-up structure of low intensity } \\
\text { - } \quad \text { pressure for development and increased anthropogenic activities } \\
\text { - } \quad \text { processes related with the abandonment of land, of cultural heritage objects, agricultural } \\
\text { buildings, and re-naturalization of territories }\end{array}$ \\
\hline & & $\begin{array}{l}\text { Potential of rurban areas } \\
\cdot \quad \text { good accessibility to rurban areas from central cities }\end{array}$ \\
\hline & & $\begin{array}{l}\text { Management of rurban areas } \\
\text { - } \quad \text { diverse mix of valuable cultural and natural features and territories } \\
\text { extensive urbanization patterns with the majority of urban expansion concentrated } \\
\text { alongside the transport routes and some dispersion of urbanization into the countryside } \\
\text { mainly based on the expansion of the existing settlements } \\
\text { - } \quad \text { development mainly within the borders of the city territory } \\
\text { priority territories for industry, logistics, and commerce are concentrated alongside the } \\
\text { transport routes }\end{array}$ \\
\hline \multirow[t]{3}{*}{ Locality level } & \multirow{3}{*}{$\begin{array}{l}\text { Detailed plans of Kaunas City } \\
\text { municipality } \\
\begin{array}{l}\text { Detailed plans of Vilnius District } \\
\text { municipality }\end{array} \\
\text { Detailed plans of Klaipeda } \\
\text { District municipality }\end{array}$} & $\begin{array}{l}\text { Rural-urban influence } \\
\text { - } \quad \text { reflection and tools of urbanization of the countryside } \\
\text { - } \quad \text { land use change from agricultural to residential }\end{array}$ \\
\hline & & $\begin{array}{l}\text { Rurban landscape characteristics } \\
\text { - } \quad \text { residential function, mainly suburban individual housing in rurban areas } \\
\text { - } \quad \text { low density point-like or patch like structure of rurban areas }\end{array}$ \\
\hline & & $\begin{array}{l}\text { Management of rurban areas } \\
-\quad \text { tool for land conversion }\end{array}$ \\
\hline
\end{tabular}

ed alongside the transport routes. Cultural heritage objects with the envisioned protection zones are concentrated alongside the historic routes [9]. Thus the planning documents reveal the different character of development of these two district municipalities and the attempts to maintain it by means of territorial planning.
However, the solutions of the municipality level territorial planning documents and their impact on landscape attain much criticism from the researchers that usually conclude that the extent of territorial expansion of urbanization into the countryside and the natural areas and its character are often driven by 
commercial interests; meanwhile the local planning documents (the detailed plans) often serve as a mere tool of land conversion [3], [16]. P. Aleknavicius and J. Valciukiene note the pressure of urban expansion on the valuable agricultural land and the failure of contemporary territorial planning to sustainably coordinate the arrangement of the built-up and natural areas, to evaluate the aesthetic impact and the impact on the agriculture of the proposed landscape transformations [5].

\section{Conclusion}

1. The analysis of the selected territorial planning documents of different levels valid in the territory of Lithuania demonstrates the presence of rural-urban interface and related problems in the zones of influence of the large cities of the country (Table I).

2. Natural conditions, functions, structure, and management problems of rurban areas as reflected in territorial planning documents allow concluding on their identity: transitory nature in layout, spatial structure and uses, changing dynamic character with present processes of rapid urbanization and abandonment; decline of heritage and agricultural buildings and re-naturalization of territories, increasing functional, layout, spatial and resulting aesthetic and ecological fragmentation and increasing complexity.

3 . The analysis shows that the potential of rurban areas lies in understanding that they are the accumulation and representatives of country's heritage and diverse and expressive landscape, present favourable communication possibilities due to their integration in the formation of the image of urban area.

4. The emphasis on the complexity of the approach and the planning of the spatial structure of territories embodied in the contemporary territorial planning legislation of the country and the array of possible types of planning documents theoretically allow the sustainable development of rurban areas by means of territorial planning in Lithuania.

\section{REFERENCES}

1. Adell, G. Theories and Models of the Peri-urban Interface : a Changing Conceptual Landscape. London: Development Planning Unit, UCL, 1999 [online]. UCL [cited 22.04.2016]. http://discovery.ucl.ac.uk/43/

2. Allen, A. Environmental Planning and Management of Peri-urban Interface : Perspective on an Emerging Field. Environment and Urbanization, 2003, No. 1 (15), p. 135-148. https://doi.org/10.1177/095624780301500103

3. Ramanauskas, E., Dringelis, L. The Impact of Urban Planning on the Development of Territorial Land Resources : Experience in Lithuania. Architecture and Urban Planning, 2013, No. 8, p. 34-39. https://doi.org/10.7250/ aup.2013.017

4. Lietuvos Respublikos teritorijų planavimo ịstatymas (Law on Territorial Planning of the Republic of Lithuania) [online, cited 22.04.2016]. http:/ www3.lrs.lt/pls/inter3/dokpaieska.showdoc_1?p_id=478619

5. Aleknavičius, P. Valčiukienė, J. Kaimiškojo kraštovaizdžio raidos ypatumai Vilniaus miesto įtakos zonoje (Features of Rural Landscape Development in Vilnius City Influence Zone). Vandens ükio inžinerija, 2011, No. 38 (58), p. 32-41.

6. Lietuvos Respublikos teritorijos bendrasis planas (General Plan of the Territory of the Republic of Lithuania) [online, cited 20.12.2015]. https:// map.tpdr.lt/tpdr-gis/index.jsp?action=tpdrPortal\&reg_tpd_id $=52605$
7. Nacionalinio kraštovaizdžio tvarkymo plano sprendiniai (Solutions of the National Landscape Management Plan of the Republic of Lithuania) [online, cited 22.04.2016]. http://www.am.lt/VI/index.php\#a/12733

8. Vilniaus Rajono savivaldybès teritorijos kraštovaizdžio specialusis planas (Special Landscape Plan of Vilnius District Municipality) [online, cited 20.01.2016]. http://teritorijuplanavimas.vrsa.lt/go.php/Specialieji-planai63916101118

9. Kauno rajono savivaldybès bendrasis planas (General Plan of Kaunas District Municipality) [online, cited 19.12.2015]. http://www.kaunoplanas.lt/ bendrieji_planai/kauno_rajono_savivaldybes_bendrasis_planas_tikroji_bukle

10. Vilniaus rajono savivaldybės teritorijos dalies (,U zonos“) bendrasis planas (General Plan of the Part of Vilnius District Municipality the „U Zone“) [online, cited 19.12.2015]. http://teritorijuplanavimas.vrsa.lt/go.php/Bendrasis-planas911692399861

11. Klaipèdos rajono savivaldybès detalieji planai (Detailed plans of Klaipeda District municipality) [online, cited 20.06.2016]. http://www.tpdris.lt/web/ guest/klaipedos-raj.

12. Kauno miesto savivaldybès detalieji planai (Detailed plans of Kaunas City municipality) [online, cited 20.06.2016] http://www.kaunas.lt/urbanistika/ detalieji-planai/

13. Vilniaus rajono savivaldybès detalieji planai (Detailed plans of Vilnius City municipality. [online, cited 20.06.2016]. http://www.vrsa.lt/go.php/ lit/Informacija-apie-teritoriju-planavima/232

14. Klaipėdos rajono savivaldybès teritorijos kraštovaizdžio tvarkymo specialusis planas [online, cited 20.06.2016]. http://www.webpartner.lt/klaipeda $\mathrm{raj} / \mathrm{subsystems/web/doc.php?itemID=13218}$

15. Kauno miesto bendrasis planas (General Plan of Kaunas) [online, cited 20.06.2016] http://www.kaunoplanas.lt/bendrieji_planai/sprendiniai_2

16. Gaudèšius, R. Landscape Architecture Features in Urban Junction of Sendvaris District and Klaipéda City. Environmental Research, Engineering and Management, 2013, No. 2 (64), p. 72-80. https://doi.org/10.5755/ j01.erem.64.2.4018 


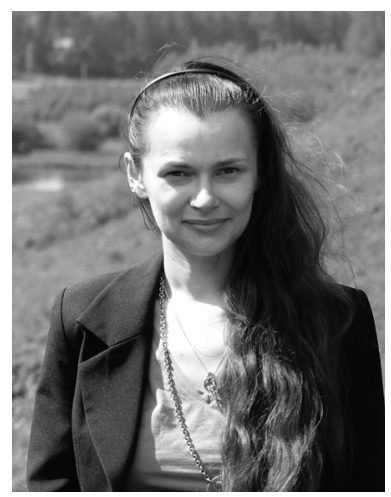

Indrẻ Gražulevičiūtė-Vileniškè received the Bachelor degree in Architecture in 2003, the Master degree in Land Management in 2005 and the degree of Doctor of Technological Sciences in 2009 from Kaunas University of Technology.

In 2009-2012, she was a Lecturer with the Department of Architecture and Land Management of the Faculty of Civil Engineering and Architecture, Kaunas University of Technology,

Since 2012, she has been an Associated professor with the Department of Architecture and Urbanism of the Faculty of Civil Engineering and Architecture.

Her current and previous research interests are valuation and preservation of cultural heritage, management of rural-urban interface, sustainable architecture.

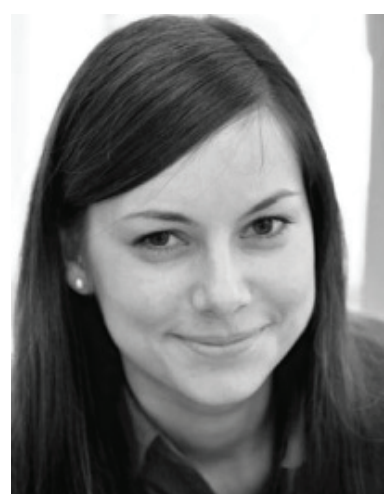

Erika Zaleskienè received the Bachelor degree in Forestry (landscape gardening) from Šiauliai University in 2009, the Master degree in Landscape Architecture from Klaipeda University in 2011. Since 2012, she has been a Ph. D. student with Kaunas University of Technology.

In 2010-2013, she was an Assistant with the Department of Environmental Research of Šiauliai University. Since 2013, she has been a Lecturer with the Department of Environmental Research of Siauliai University. Her current and previous research interests are formation of green areas, rural-urban interface, rurban landscapes, landscape aesthetics.

\section{Contact Data}

Indrẻ Gražulevičiūtè-Vilenišké

Department of Architecture and Urbanism, Faculty of Civil Engineering and Architecture, Kaunas University of Technology

Address: 48 Studentu St., Kaunas, LT-51367, Lithuania

Phone: +370 37451546

E-mail: indre.grazuleviciute@ktu.lt

*Corresponding author

\section{Erika Zaleskienè}

Department of Architecture and Urbanism, Faculty of Civil Engineering and Architecture, Kaunas University of Technology

Address: 48 Studentu St., Kaunas, LT-51367, Lithuania

Phone: +370 37451546

E-mail: erika.brinkyte@gmail.com 